\title{
Psykologiset perustarpeet työelämässä - autonomian edistämisellä kohti työn imua
}

\begin{abstract}
Abstrakti
Nykyisen työelämän painottuminen asiantuntijatyöhön luo tarvetta uudenlaiselle, erityisesti työntekijöiden autonomiaa edistävälle johtamiselle. Tämän tutkimuksen tarkoituksena on tuoda lisätietoa työntekijöiden autonomian tarpeen täyttymisen merkityksestä työhyvinvoinnille. Tutkimuksessa tarkastellaan psykologisten perustarpeiden (autonomian, kompetenssin ja yhteenkuuluvuuden) välittävää roolia valtuuttavan johtamisen ja työntekijöiden kokeman työn imun välillä, sekä erityisesti sitä, välittääkö tarpeiden peräkkäinen täyttyminen tätä yhteyttä. Itsemääräytymisteoriaan ja JD-R-malliin pohjautuen tutkimushypoteeseiksi asetettiin, että valtuuttavan johtamisen yhteys työn imuun välittyy sekä autonomian ja kompetenssin että autonomian ja yhteenkuuluvuuden peräkkäisen täyttymisen kautta. Tutkimushenkilöt ( $n=110)$ osallistuivat Kansaneläkelaitoksen järjestämään, ammatillisesti syvennettyyn lääketieteelliseen ASLAK-kuntoutukseen. Osana kuntoutustaan he vastasivat erilaisiin itsearviointikyselyihin, joilla selvitettiin käsityksiä työn ominaisuuksista (QPSNordic), psykologisten perustarpeiden täyttymisestä työssä (WBNS-FI) sekä koetusta työn imusta (UWES-9). Regressio- ja bootstrap-analyysien tulokset tukivat asetettuja hypoteeseja: psykologisten perustarpeiden peräkkäiset täyttymiset välittävät valtuuttavan johtamisen yhteyttä työn imuun. Teoreettisen merkittävyyden ohella tuloksilla on käytännön sovellusarvoa organisaatioille ja työyhteisöille kustannustehokkaasti ja vaivattomasti.
\end{abstract}

\section{Johdanto}

Viime vuosikymmenten yhteiskunnalliset muutokset digitalisaatiosta globalisaatioon ja koulutustason nousuun ovat muokanneet työelämää yksilöllisempään suuntaan: organisaatiohierarkiat ovat madaltuneet ja perinteinen autoritaarinen johtamiskulttuuri heikentynyt (Järvensivu \& Piirainen 2015). Itseohjautuvuus onkin yksi työelämän ajankohtaisimmista trendeistä. Työntekijöiden odotetaan ottavan entistä enemmän vastuuta niin työstään - ajoista, paikoista ja tekemisen tavoista - kuin sen lopputuloksista- kin (Martela \& Jarenko 2017). Organisaatioilla on jatkuva tarve kehittyä, sillä liiketoimintaympäristön muutostahti ja kilpailu ovat entistä kovempia (Ahonen 2013). Säilyttääkseen elinvoimansa ja kilpailukykynsä organisaatioiden tulee paitsi rekrytoida päteviä työntekijöitä, myös tietoisesti ja tavoitteellisesti edistää tämän osaamispotentiaalin vapautumista; huolehtia hyvien työsuoritusten, innovaatioiden ja hyvinvoinnin edellytyksistä esimerkiksi johtamisella ja työjärjestelyillä.

Työelämän ja organisaatioiden toimintakulttuurien muutosten rinnalla myös yksilöi- 
den suhtautuminen työhön on muuttunut. Työ ei ole ainoastaan välttämätön tulonlähde, vaan myös väylä toteuttaa itseään ja arvojaan. Yksilöt haluavatkin yhä useammin ammentaa työstään merkityksellisyyttä eli kokemuksia siitä, että työ on henkilökohtaisesti merkitsevää ja itsessään arvokasta (Lysova ym. 2019). Pelkän työtyytyväisyyden sijaan haetaan esimerkiksi innostusta, omistautumista ja uppoutumista sekä kokemuksia työn imusta (Järvensivu \& Piirainen 2015). Työn kautta on myös mahdollista täyttää psykologisia perustarpeita, kompetenssia, autonomiaa ja yhteenkuuluvuutta: tuntea itsensä osaavaksi, autonomiseksi ja osaksi ryhmää (Deci ym. 2017).

Edellä kuvatut työelämän ja työtä koskevien asenteiden muutokset asettavat uudenlaisia mahdollisuuksia ja haasteita myös esimiestyölle. Perinteiselle valvovalle johtamiselle ei ole aikaa, eikä toimintakulttuurin muuttuessa myöskään tarvetta, joten esimiesten tulee ennen kaikkea tukea työntekijöiden itsensä johtamista sekä osallistumista päätöksentekoon ja innovointiin (Alasoini 2015). Näin esimiesten on astuttava pois perinteisestä auktoriteettiasemasta lähemmäs työntekijöitä ja annettava heille aiempaa enemmän vastuuta ja vapautta vaikuttaa omaan työhönsä, siis valtuutettava heitä ja tuettava erityisesti heidän autonomian tarpeitaan.

Decin ja Ryanin (2017) mukaan autonomian tukeminen edesauttaa muiden psykologisten perustarpeiden täyttymistä, minkä vuoksi sen tutkiminen ja tukeminen on perusteltua. Autonomian erityisroolia ei ole kuitenkaan huomioitu aiemmissa tutkimuksissa riittävästi, vaikka erityisroolin tutkimisella on teoreettisen perustan lisäksi käytännöllistä hyödynnettävyyttä. Autonomialle - omaan toimintaan vaikuttamiselle ja itselle merkityksellisten asioiden työstämiselle - on sekä kysyntää että tarjontaa nykytyöelämässä. Yhä useammat organisaatiot tarjoavat autonomian kokemuksia esimerkiksi rohkaisemalla kokeiluihin ja vaikuttamiseen sekä järjestämällä itseohjautuvaa tiimityötä ja työaikajoustoja (Työ- ja elinkeinoministeriö 2019).
Autonomiaa vaaditaan myös aikaisempaa enemmän, sillä työntekijät kouluttautuvat entistä korkeammalle ja odottavat työltään merkityksellisyyttä; mahdollisuuksia vaikuttaa sekä toimia itselle henkilökohtaisesti tärkeiden asioiden parissa. Kokemus omasta autonomiasta nähdään keskeisenä tekijänä työn merkityksellisyydessä, sillä sen nähdään kumpuavan muun muassa kyvystä toteuttaa työtehtäviä omaehtoisesti ja itselle sopivalla tavalla (Martela \& Pessi 2018).

Autonomiaa, kuten muitakin psykologisia perustarpeita, voidaan tukea varsin vaivattomasti ja kustannustehokkaasti arkisessa vuorovaikutuksessa sekä työjärjestelyin. Psykologiset perustarpeet ovat työyhteisöille myös kestävä sijoituskohde, sillä ne ovat universaaleja ja ajankohtaisia aina, organisaatiomuutoksista tai työelämän trendeistä riippumatta. Psykologisten perustarpeiden täyttyminen tuo myönteisiä tuloksia sekä yksilöille että organisaatioille. Työntekijöiden kohentunut hyvinvointi, motivaatio ja työssä jaksaminen näkyvät organisaatioiden menestyksessä ja kilpailukyvyssä niin lyhyellä kuin pitkälläkin aikavälillä (Deci \& Ryan 2017).

Tarkastelemme tutkimuksessamme valtuuttavan johtamisen yhteyttä työntekijöiden kokemaan työn imuun sekä erityisesti sitä, miten psykologisten perustarpeiden - autonomian, yhteenkuuluvuuden ja kompetenssin - täyttyminen välittää tätä yhteyttä, eli kuinka valtuuttava johtaminen on epäsuorasti yhteydessä työn imuun. Pyrimme tutkimuksessamme lisäämään osaltamme myös ymmärrystä autonomian täyttymisen merkityksestä työssä sekä tarjoamaan esimiehille keinoja edistää työntekijöiden psykologisten perustarpeiden täyttymistä rekrytoinnista lähtien.

\section{Valtuuttava johtaminen}

Valtuuttava johtaminen (empowering leadership) viittaa esimieskäytäntöihin, joilla pyritään tietoisesti lisäämään työntekijöiden vaikutusmahdollisuuksia, vastuuta ja vapautta esimer- 
kiksi itseohjautuvia tiimejä luomalla tai työtehtäviä monipuolistamalla (Lämsä \& Päivike 2013). Sen taustalla on näkemys henkilöstöstä laadun, tiedon ja innovaatioiden kehittäjänä.

Valtuuttamisessa esimiehen tehtävänä on taata työntekijöille tarvittavia resursseja, kuten aikaa, rahaa, työtiloja ja -välineitä sekä lisäkoulutusmahdollisuuksia, jotta he voivat toteuttaa aikaisempaa monipuolisempia ja vastuullisempia työtehtäviä (Lämsä \& Päivike 2013). Esimiehen tulee myös huolehtia vastuun ja vapauden tasapainosta sekä tukea ja edistää työntekijöiden oma-aloitteisuutta, motivaatiota ja itseluottamusta. Valtuuttavaan johtamiseen liittyy niin ikään kiinteästi esimiehen ja alaisten välinen luottamus sekä hierarkkisen valtasuhteen purkaminen.

Valtuuttavaa johtamista voidaan tarkastella esimerkiksi rakenteellisen ja psykologisen valtuuttamisen käsitteiden avulla (Maynard ym. 2012). Rakenteellinen valtuuttaminen keskittyy työn ominaisuuksiin, kuten tiimi- ja tehtäväjärjestelyihin, jotka vaikuttavat vallan, vaikutusmahdollisuuksien ja resurssienhallinnan jakamiseen (Kanter 1977). Näin organisaation tarkoituksenmukaiset työjärjestelyt ja -tavat edeltävät yksilöiden aidon valtautumisen, autonomian, vaikutusmahdollisuuksien ja päätösvallan toteutumista (Lämsä \& Päivike 2013).

Psykologinen valtuuttaminen (psychological empowerment) viittaa puolestaan työntekijöiden tulkintoihin heidän todellisista mahdollisuuksistaan vaikuttaa työhönsä (Maynard ym. 2012; Spreitzer 1995). Rakenteellisesta valtuuttamisesta poiketen kyse ei ole siitä, kuinka vastuu ja velvollisuudet on käytännössä jaettu, vaan työntekijöiden kognitiivisista arvioista ja käsityksistä toteutetusta valtuuttamisesta - ja ennen kaikkea sen onnistuneisuudesta. Työntekijät voivat tuntea toimintansa vapaaehtoiseksi ja itselle merkitykselliseksi esimiehen tarjotessa heille riittävästi tukea, vastuuta ja vaikutusmahdollisuuksia. Näin valtuuttava johtaminen näyttäytyy erityisesti yksilöiden autonomiaa tukevana työn voimavarana.

\section{Työn voimavarojen ja vaatimusten malli}

Työn voimavarojen ja vaatimusten malli eli JD-Rmalli on nykyisin eniten käytetty teoria työn imun tutkimuksessa (Hakanen \& Roodt 2010). Mallissa työn voimavarat ovat psykologisia, sosiaalisia, organisatorisia ja fyysisiä resursseja, jotka mahdollistavat tavoitteiden saavuttamisen, lieventävät tai suojaavat työn vaatimuksilta ja mahdollistavat työntekijän kasvun ja kehityksen (Bakker \& Demerouti 2017). Valtuuttava johtaminen voi olla mallissa yksi työn voimavaroista, joka edistää työntekijöiden hyvinvointia, kuten työn imua. Työn vaatimukset taas ovat työn psykologisia, sosiaalisia, organisatorisia ja fyysisiä aspekteja, jotka kuluttavat psyykkistä ja fyysistä energiaa.

Työn voimavarat ja vaatimukset voivat johtaa kahteen erilaiseen psykologiseen prosessiin: energiat ehdyttävään ja terveyttä huonontavaan, jossa korkeat työn vaatimukset uuvuttavat työntekijän henkiset ja fyysiset voimavarat johtaen loppuunpalamiseen ja huonovointisuuteen (health impairment process) tai myönteiseen motivoivaan prosessiin, jossa työn voimavarat vahvistavat työn imua ja organisaatioon sitoutumista (motivational process) (Bakker \& Demerouti 2017). Työn voimavarat, kuten sosiaalinen tuki ja esimiessuhteen laatu, lievittävät työn vaatimusten kielteisiä vaikutuksia työhyvinvointiin (Bakker ym. 2005).

Niin energiat ehdyttävä kuin motivoivakin prosessi voi sisältää lukuisia tekijöitä tai mekanismeja, jotka selittävät, miksi työn ominaisuudet johtavat erilaisiin lopputulemiin. Työn ominaisuuksien ja niiden seurausten välinen yhteys on siis epäsuora ja kulkee näiden mekanismien kautta (Schaufeli \& Taris 2014). Tässä tutkimuksessa tarkastellaan JD-R-mallin mukaista johtamisen (työn voimavara) ja työn imun välistä myönteistä prosessia erityisesti psykologisten perustarpeiden täyttymisen näkökulmasta. Tällöin oletetaan, että psykologisten perustarpeiden täyttyminen on mekanismi, jonka kautta valtuuttava johtaminen ainakin osittain tukee motivoivaa prosessia ja näin 


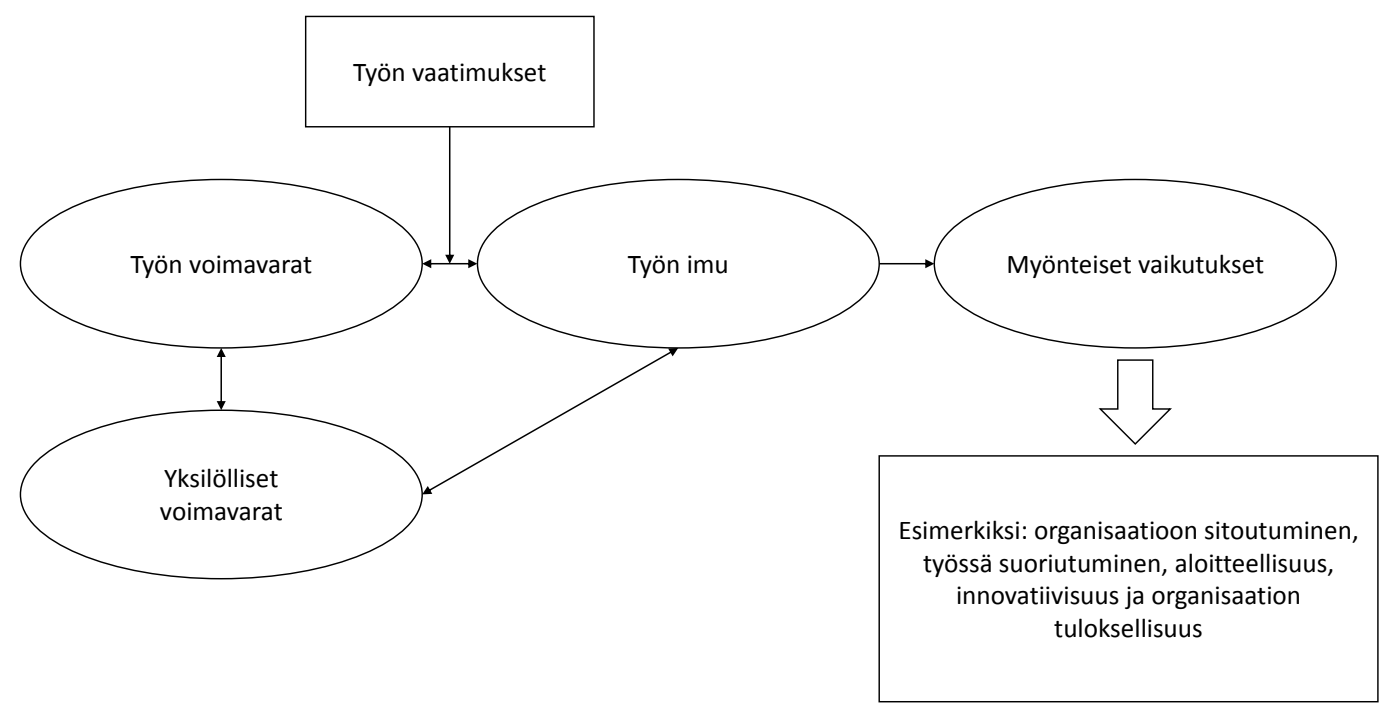

Kuvio 1. Työn imun JD-R-malli (Hakanen \& Roodt 2010)

työntekijöiden työn imua. Malli on esitetty kuviossa 1.

\section{Työn imu}

Työn imu on myönteinen, työhön liittyvän hyvinvoinnin tunne- ja motivaatiotäyttymyksen tila, joka koostuu tarmokkuudesta, omistautumisesta ja uppoutumisesta (Schaufeli \& Bakker 2010). Tarmokkuutta kuvaa energisyys ja mentaalinen resilienssi työskennellessä, omistautumista vahva sitoutuneisuus ja kokemus työn tärkeydestä, uppoutumista taas täydellinen keskittyminen ja syventyminen työskentelyyn. Työn imu liittyy haastaviin työtehtäviin ja kuvaa ihmisen kykyä käyttää kaikkea kapasiteettiaan ja energiaansa ongelmien ratkaisemiseen, kontaktien luomiseen ja innovatiivisten palveluiden kehittämiseen (Leiter \& Bakker 2010).

Työn voimavarojen, kuten sosiaalisen tuen, palautteen ja osaamisen, on havaittu olevan positiivisesti yhteydessä työn imuun (Halbesleben 2010). Työn imu on työntekijän henkilökohtainen kokemus, mutta se ei esiinny eris- tyksissä, vaan sosiaalinen ympäristö, kuten johtaminen, vaikuttaa siihen. Johtamista kehittämällä voidaan siis vaikuttaa työntekijöiden työn imuun (Biggs ym. 2014). Työn imun tukeminen esimiestyössä onkin tärkeää, kun huomioidaan sen myönteiset vaikutukset niin yksilö- kuin organisaatiotasolla (Halbesleben 2010). Työn imun on havaittu olevan positiivisesti yhteydessä muun muassa työntekijöiden fyysiseen ja psyykkiseen terveyteen sekä vähentyneisiin irtisanoutumisaikeisiin ja työuupumukseen (emt.). Myönteisen yksilöllisten vaikutusten lisäksi työn imun tukeminen on hyödyllistä koko organisaatiolle, sillä työn imu on johdonmukaisesti yhteydessä esimerkiksi sitoutumiseen (emt.), työsuoriutumiseen (Christian ym. 2011), asiakastyytyväisyyteen (Salanova ym. 2005) ja taloudelliseen tuottavuuteen (Xanthopolou ym. 2009). Parhaaksi työhyvinvoinnin tilaksikin luonnehdittua työn imua (Hakanen 2011) voidaan tukea esimerkiksi työntekijöiden psykologisten perustarpeiden huomioimisella, mikä onnistuu vaivattomasti työjärjestelyin ja arkisessa vuorovaikutuksessa. 


\section{Itsemääräytymisteoria: psykologiset perustarpeet}

Itsemääräytymisteorian (Self-Determination Theory, SDT) mukaan yksilö pyrkii luonnostaan psykologiseen kasvuun ja hyvinvointiin, omien kykyjen harjoittamiseen, haasteiden voittamiseen, sisäisen maailman eheyteen ja itsemääräytymiseen (Pervin 2003; Deci \& Ryan 2017). Itsemääräytymispyrkimys havaitaan selkeimmin sisäisenä motivaationa, eli toimintana, joka koetaan itsessään mielenkiintoiseksi ja motivoivaksi. Edellä mainitut käyttäytymistaipumukset vaativat sisäsyntyisyydestään huolimatta ympäristön tukea. Ympäristön olosuhteiden ja yksilön hyvinvoinnin välisenä linkkinä itsemääräytymisteoria näkee psykologiset perustarpeet, autonomian, kompetenssin ja yhteenkuuluvuuden.

Autonomia on mahdollisuutta säädellä toimintaa ja kokemuksia, jolloin ne koetaan vapaaehtoisiksi ja yhteneväisiksi henkilökohtaisten kiinnostuksen kohteiden ja arvojen kanssa. Autonomia ei ole täydellistä itsenäisyyttä tai riippumattomuutta toisista, vaan pikemminkin ymmärrystä esimerkiksi työn merkityksellisyydestä ja arvosta silloinkin, kun käsillä oleva tehtävä on pakollinen ja esimiehen vaatima. Decin ja Ryanin (2017) mukaan autonomia poikkeaa muista tarpeista, sillä sen täyttyminen edesauttaa usein toisten fysiologisten ja psykologisten perustarpeiden täyttymistä.

Tämä ilmenee esimerkiksi niin, että yksilö kokee olevansa kompetentti erityisesti silloin, kun hän tuntee olevansa osaava ja tehokas sellaisessa toiminnassa, jonka hän on oma-aloitteisesti tai vapaaehtoisesti ottanut hoitaakseen (Deci \& Ryan 2017). Kompetenssin tarve on tarve tuntea kyvykkyyttä: osata ja hallita tietoja ja taitoja, jotka ovat tärkeitä yksilön sosiaalisessa kontekstissa, kuten työpaikalla. Autonomian ja kompetenssin lisäksi yksilöllä on luontainen tarve tuntea yhteenkuuluvuutta - olla tärkeä, merkittävä ja välittämisen arvoinen toisten silmissä - ja välttää torjutuksi tai eristäytyneeksi joutuminen. Kompetenssin tavoin myös yhteenkuuluvuuden tarve voi täyt- tyä autonomian avustamana. Oma-aloitteinen ja toimintaansa ohjaava yksilö voi esimerkiksi hakeutua erilaisiin projekteihin työyhteisössään ja panostaa hyviin kollegiaalisiin suhteisiin.

Psykologisten perustarpeiden täyttymistä tukevat ympäristöt parantavat yksilön motivaatiota, elinvoimaisuutta, sosiaalista integraatiota sekä hyvinvointia, kun taas liian kontrolloiviksi, kriittisiksi tai torjuviksi koetut ympäristöt johtavat heikentyneeseen motivaatioon ja hyvinvointiin, kielteisiin tunteisiin ja antisosiaaliseen käyttäytymiseen (Deci \& Ryan 2017). Näin valtuuttavan johtamisen voi odottaa olevan työympäristön keskeinen ominaisuus, joka vaikuttaa autonomian sekä kompetenssin ja yhteenkuuluvuuden täyttymiseen ja näin myös yksilön motivaatioon ja hyvinvointiin työssään, esimerkiksi työn imun muodossa.

\section{Psykologiset perustarpeet työelämässä}

Psykologisten perustarpeiden merkitystä on tutkittu runsaasti työ- ja organisaatiopsykologian alalla (esim. Gillet ym. 2016; Van den Broeck ym. 2008). Yleensä työelämää ja organisaatioita koskevissa tutkimuksissa työntekijöiden henkilökohtaiset ominaisuudet ja työympäristön piirteet on määritelty riippumattomiksi muuttujiksi, joiden yhteyksiä riippuviin muuttujiin, kuten työsuorituksiin ja -hyvinvointiin, psykologisten perustarpeiden on oletettu välittävän (Deci ym. 2017). Tutkimuskohteiksi on asetettu esimerkiksi esimiesten johtamistyylien vaikutukset työntekijöiden työtyytyväisyyteen ja tuottavuuteen (esim. Gillet ym. 2011; Kovjanic ym. 2012).

Aiemmissa tutkimuksissa psykologisten perustarpeiden on osoitettu välittävän yhteyksiä muun muassa autonomiaa tukevan johtamisen ja työn imun, itsetunnon, työtyytyväisyyden sekä organisaatioon identifioitumisen välillä (Deci ym. 2001; Gillet ym. 2013). Tämä viittaa siihen, että perustarpeiden täyttyminen voisi osaltaan selittää, miksi jotkin joh- 
tamistavat voivat edesauttaa JD-R-mallin kuvaamaa motivoivaa prosessia. Myös Van den Broeckin ja kollegojen (2016) 99 tutkimuksen ja 119 erillisen otoksen kattavassa metaanalyysissä autonomiaa tukevan johtamisen todettiin olevan tilastollisesti merkitsevästi positiivisessa yhteydessä psykologisiin perustarpeisiin, ja perustarpeiden täyttymisen taas koettuun työn imuun.

Autonomian, yhteenkuuluvuuden ja kompetenssin täyttymistä on tavallisesti tutkittu näiden kolmen psykologisen perustarpeen yhdistelmänä huomioimatta tarpeiden keskinäistä dynamiikkaa tai sitä, että ne eivät aina täyty tasaisesti (Deci ym. 2017). Monissa tutkimuksissa on kuitenkin tarkasteltu pelkästään autonomian tarpeen tukemista, sillä sen on havaittu korreloivan voimakkaasti kompetenssin ja yhteenkuuluvuuden tarpeiden täyttymisen kanssa. Autonomian tukemisen ja kahden muun psykologisen perustarpeen toteutumisen välistä yhteyttä on selitetty yhtäältä organisaation esimieskäytännöillä ja toisaalta myös työntekijöiden omalla toiminnalla. Työntekijöiden autonomiaa edistävät esimiehet huomioivat ja tukevat myös kompetenssin ja yhteenkuuluvuuden täyttymistä, ja toisaalta itsensä autonomisiksi kokevat työntekijät löytävät keinoja tuntea itsensä myös päteviksi ja osaksi työyhteisöä (Deci \& Ryan 2017).

Deci ja Ryan (2017) huomauttavat autonomian olevan usein ratkaisevassa asemassa kompetenssin ja yhteenkuuluvuuden tarpeiden täyttymisessä, sillä sen mahdollistama vapaus vaikuttaa omaan toimintaansa on välttämätöntä itsesäätelylle ja oma-aloitteisuudelle, joiden kautta taas muut tarpeet tunnistetaan ja huomioidaan helpommin. Autonomian toteutuminen toimii siis ikään kuin väylänä toteuttaa kahta muuta psykologista perustarvetta itselle sopivalla ja merkityksellisellä tavalla.

Autonomian erityisroolia huomioivaa tutkimusta on kuitenkin varsin niukasti, vaikka erityisroolin tarkastelu olisi itsemääräytymisteoriaan pohjautuen perusteltua. Tämän tut- kimuksen tavoitteena on lisätä tietoa autonomian merkityksestä työelämässä erityisesti valtuuttavan johtamisen ja työntekijöiden kokeman työn imun näkökulmasta. Pyrkimyksenä on selvittää tarpeiden mahdollista dynamiikkaa eli mahdollisuutta, että valtuuttava johtaminen on yhteydessä kompetenssin ja yhteenkuuluvuuden tarpeiden täyttymiseen autonomian täyttymisen kautta, ja että näiden tarpeiden täyttyminen selittäisi valtuuttavan johtamisen ja työn imun yhteyttä. Kausaalisesti tulkittuna tämä tarkoittaisi sitä, että valtuuttava johtaminen edesauttaa työntekijöiden autonomian tarpeen täyttymistä. Tällöin he puolestaan omaan toimintaansa vaikuttamalla ja valitsemalla erilaisia aktiviteetteja voivat löytää keinoja toteuttaa kompetenssin ja yhteenkuuluvuuden tarpeita, siis tuntea itsensä osaaviksi ja osaksi työyhteisöä ja kyetä näin olemaan myös tarmokkaita, omistautuneita ja uppoutuneita työhönsä - kokemaan työn imua.

Tämä psykologisten perustarpeiden täyttyminen voi osin selittää, miksi valtuuttava johtaminen on yhteydessä työntekijöiden kokemaan työn imuun. Yksilöt toimivat tarmokkaasti, omistautuvat ja uppoutuvat työhönsä tuntiessaan olevansa autonomisia, osaavia ja kuuluvansa joukkoon työpaikalla, jossa esimies tukee heitä sekä antaa vastuuta ja vaikutusmahdollisuuksia. Hypoteettinen selitysmalli on esitetty kuviossa 2 . Itsemääräytymisteorian ja JD-R-mallin perusteella (Deci \& Ryan 2017; Bakker \& Demerouti 2017) hypoteeseiksi asetetaan:

1) Autonomian täyttyminen välittää valtuuttavan johtamisen ja työn imun yhteyden.

2) Autonomian ja kompetenssin peräkkäinen täyttyminen välittää valtuuttavan johtamisen ja työn imun yhteyden.

3) Autonomian ja yhteenkuuluvuuden peräkkäinen täyttyminen välittää valtuuttavan johtamisen ja työn imun yhteyden. 


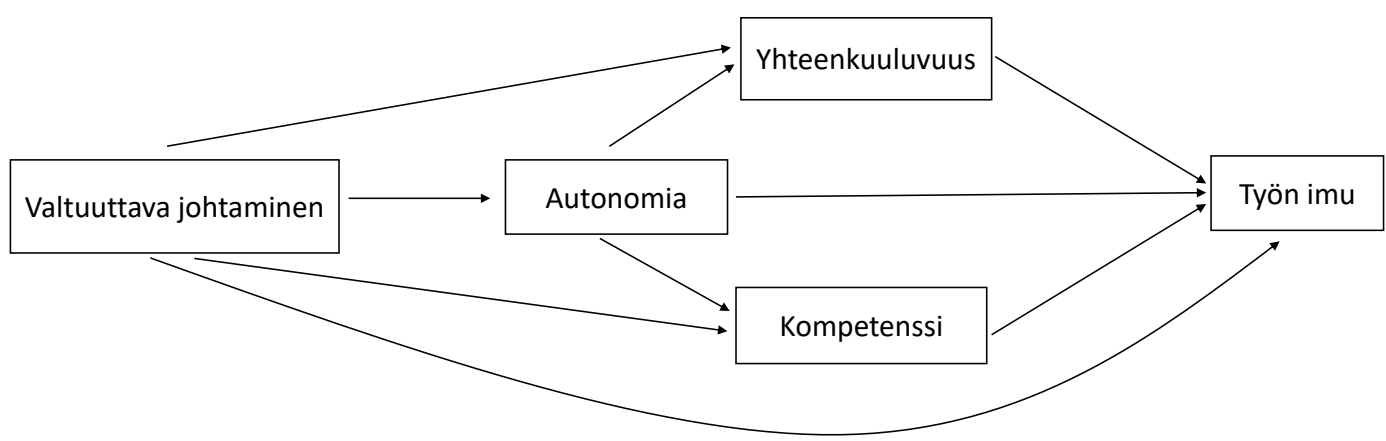

Kuvio 2. Hypoteettinen selitysmalli

\section{Aineisto ja menetelmät}

\section{Osallistujat}

Tutkimusaineistomme koostuu pääosin keskiikäisistä, työssäkäyvistä henkilöistä, jotka ovat osallistuneet Kansaneläkelaitoksen järjestämään ammatillisesti syvennettyyn lääketieteelliseen kuntoutukseen (ASLAK). ASLAK-varhaiskuntoutuksen tavoitteena on edistää työikäisten elämänhallintaa sekä työ- ja toimintakykyä siinä vaiheessa, kun he ovat vielä verrattain hyvinvoivia, mutta selkeitä työ- ja toimintakyvyn heikkenemisen riskejä on kuitenkin jo havaittavissa (Kansaneläkelaitos 2012). Kuntoutukseen osallistuvien työhön liittyy tavallisesti merkittävää fyysistä, psyykkistä tai sosiaalista kuormitusta, jolloin työterveys- ja hyvinvointiongelmien ennaltaehkäisy ja varhainen hoitaminen nousevat ensiarvoisen tärkeiksi työkyvyn ja työssä jaksamisen kannalta.

Tutkimukseen osallistujat vastasivat osana kuntoutustaan erilaisiin itsearviointiin perustuviin kyselyihin, joilla selvitettiin muun muassa työn imua, työn ominaisuuksia sekä työhön liittyviä psyykkisiä ja sosiaalisia teki- jöitä. Tutkimuksen kyselyihin (Utrecht Work Engagement Scale ja QPSNordic) vastattiin sähköisesti osana kuntoutusta riippumatta siitä, osallistuivatko kuntoutujat tutkimukseen vai eivät. Psykologisten perustarpeiden täyttymistä selvittävä kysely (WBNS-FI) pyydettiin täyttämään erikseen. Tutkimusaineisto koostuu näistä vastauksista osallistujien vapaaehtoisuuteen ja suostumukseen perustuen. Puuttuvat tiedot (11 kpl) korvattiin osallistujan omalla keskiarvolla asteikossa. Kansaneläkelaitos ja kuntoutuskeskus antoivat luvan aineiston hankintaan. Kuopion yliopistollisen sairaalan tutkimuseettinen toimikunta puolsi tutkimuksen toteuttamista.

Tutkimukseen osallistujista $(\mathrm{N}=110)$ suurin osa, 86 prosenttia, oli naisia. Osallistujat olivat 33-63-vuotiaita keski-iän ollessa noin 50 vuotta. Valtaosa heistä oli suorittanut ylioppilastutkinnon (75\%) ja ammatillisena koulutuksena korkeakoulun tai yliopiston (46\%). Lähes kaikki osallistujat olivat kokopäiväisessä ansiotyössä, ja he työskentelivät useilla aloilla. Tarkemmat tiedot tutkimukseen osallistujista löytyvät taulukosta 1 . 
TAULUKKO 1. Osallistujien taustatiedot

\begin{tabular}{|c|c|}
\hline Taustatieto & Määrä tai osuus \\
\hline Ikä vuosina $K A(K H)$ & $50.5(6.4)$ \\
\hline Miehiä/naisia (n) & $16 / 94$ \\
\hline Miehiä/naisia (\%) & $15 / 86$ \\
\hline \multicolumn{2}{|l|}{ Siviilisääty (\%) } \\
\hline naimisissa tai avoliitossa & 77 \\
\hline eronnut & 14 \\
\hline naimaton & 8 \\
\hline \multicolumn{2}{|l|}{ Peruskoulutus (\%) } \\
\hline kansa- tai kansalaiskoulu & 3 \\
\hline peruskoulu & 19 \\
\hline keskikoulu & 4 \\
\hline ylioppilastutkinto & 75 \\
\hline \multicolumn{2}{|l|}{ Ammatillinen koulutus (\%) } \\
\hline kurssimuotoinen & 1 \\
\hline ammattikoulu & 3 \\
\hline opistotaso & 33 \\
\hline ammattikorkeakoulu & 15 \\
\hline korkeakoulu tai yliopisto & 46 \\
\hline \multicolumn{2}{|l|}{ Työtilanne (\%) } \\
\hline kokopäivätyössä & 97 \\
\hline osa-aikatyössä & 3 \\
\hline \multicolumn{2}{|l|}{ Ammattiala (\%) } \\
\hline tekninen, tieteellinen, lainopillinen tai humanistinen ala & 45 \\
\hline terveydenhuolto- tai sosiaaliala & 27 \\
\hline hallinto- ja toimistotyö & 17 \\
\hline kaupallinen työ ja palvelutyö & 10 \\
\hline teollinen työ, koneenhoito, kaivos-, louhinta- tai rakennustyö & 1 \\
\hline
\end{tabular}

$K A=$ keskiarvo, $K H=$ keskihajonta

\section{Arviointimenetelmät}

QPSNordic-yleiskyselyllä (Elo ym. 2001) selvitettiin osallistujien kokemuksia valtuuttavasta johtamisesta ( 3 osiota, $\alpha=.88$ ) esimerkiksi kysymyksellä "Rohkaiseeko lähin esimiehesi sinua osallistumaan tärkeisiin päätöksiin?". Kysymyksiin vastattiin itsearvioinnein viisiportaisella asteikolla (1=harvoin tai ei koskaan, 5=hyvin usein tai aina).

Psykologisten perustarpeiden täyttymistä työssä tarkasteltiin Van den Broeckin ja kumppaneiden (2010) kehittämän Work-Related Basic Need Satisfaction -mittarin suomennetulla versiolla (WBNS-FI; Karkkola ym. 2019.) Tässä itsearviointikyselyssä osallistujat vastasivat psykologisten perustarpeiden täyttymistä kuvaaviin väitteisiin asteikolla yhdestä viiteen (1= täysin eri mieltä, $5=$ täysin samaa mieltä). WBNS-FI koostuu yhteensä 18 väit- tämästä, jotka kuvaavat työntekijöiden kokemuksia autonomian (esim. "Saan tehdä työt omalla tavallani", $\alpha=.78$ ), kompetenssin (esim. "Tunnen pystyväni suoriutumaan jopa vaikeimmista työtehtävistä", $\alpha=.88$ ) ja yhteenkuuluvuuden (esim. "Töissä tunnen olevani osa porukkaa", $\alpha=.84$ ) täyttymisestä.

Schaufelin ja Bakkerin (2010) Utrecht Work Engagement -kyselyn (UWES-9) yhdeksänosioisella suomenkielisellä versiolla (Työn imu 9 -kysely, Hakanen 2009) selvitettiin työn imun kokemuksia $(\alpha=.92)$ esimerkiksi väittämillä "Tunnen itseni vahvaksi ja tarmokkaaksi työssäni", "Olen ylpeä työstäni" ja "Kun työskentelen, työ vie minut mukanaan". Osallistujien tuli arvioida edellä kuvattujen tuntemusten toistuvuutta työssään asteikolla nollasta kuuteen $(0=$ en koskaan, $6=$ päivittäin). 
TAULUKKO 2. Asteikkojen sisäinen johdonmukaisuus ja keskinäiset korrelaatiot

\begin{tabular}{|c|c|c|c|c|c|c|c|c|}
\hline & Asteikko & $\mathrm{KA}$ & $(\mathrm{KH})$ & $\alpha$ & 1 & 2 & 3 & 4 \\
\hline 1 & autonomian täyttyminen ${ }^{1}$ & 3,6 & $(0.60)$ & .78 & & & & \\
\hline 2 & kompetenssin täyttyminen $^{1}$ & 3,8 & $(0.66)$ & .88 & $.48^{*}$ & & & \\
\hline 3 & yhteenkuuluvuuden täyttyminen ${ }^{1}$ & 3,9 & $(0.70)$ & .84 & $.50^{*}$ & $.62 *$ & & \\
\hline 4 & työn imu² & 4,6 & $(1.01)$ & .92 & $.55^{*}$ & $.52 *$ & $.54^{*}$ & \\
\hline 5 & valtuuttava johtaminen ${ }^{3}$ & 3,4 & $(1.02)$ & .88 & $.30^{*}$ & .18 & $.25^{*}$ & $.27^{*}$ \\
\hline
\end{tabular}

\section{Tilastoanalyysi}

SPSS-tilastoanalyysiohjelmistolle kehitetyllä PROCESS-lisäosalla (Hayes 2017) tutkittiin, välittääkö työntekijöiden psykologisten perustarpeiden peräkkäinen täyttyminen valtuuttavan johtamisen ja työntekijöiden kokeman työn imun välistä yhteyttä. Välittämistä eli mediaatiota testatessa selvitetään, mikä on se mekanismi, jonka kautta riippumaton muuttuja on yhteydessä riippuvaan muuttujaan. Mediaatio kuvaa tilannetta, jossa jokin kolmas muuttuja (välittävä muuttuja) toimii kahden muun muuttujan välisenä linkkinä, ikään kuin siltana: riippumaton muuttuja on yhteydessä välittävään muuttujaan, joka taas on yhteydessä riippuvaan muuttujaan. Näin riippumattoman muuttujan yhteys riippuvaan muuttujaan välittyy epäsuorasti, kolmannen muuttujan kautta. Peräkkäisessä mediaatiossa riippumattoman ja riippuvan muuttujan välissä on vähintään kaksi välittävää muuttujaa, jotka ovat linkittyneitä toisiinsa.

Tässä tutkimuksessa selvitettiin, välittääkö psykologisten perustarpeiden peräkkäinen täyttyminen (autonomia-kompetenssi, autonomia-yhteenkuuluvuus) valtuuttavan johtamisen yhteyttä työntekijöiden kokemaan työn imuun: onko valtuuttava johtaminen siis yhteydessä työn imuun siten, että se tukee työntekijöiden autonomiaa sekä kompetenssiin ja yhteenkuuluvuuden tarpeiden täyttymistä, mikä puolestaan on yhteydessä koettuun työn imuun. Muuttujien välisiä yhteyksiä kuvataan korrelaatiokertoimilla (Taulukko 2) ja niiden keskinäisiä selitysosuuksia regressiomallien selitysosuuksilla $\left(\mathrm{R}^{2}\right)$ sekä standardoimattomilla regressiokertoimilla $(\beta)$ ja yhteyksien merkitsevyyksiä 95 prosentin luottamusväleillä (LV). Epäsuorien yhteyksien voimakkuuksia kuvataan niiden prosentuaalisilla osuuksilla kokonaisyhteydestä (Pm, percent mediation).

PROCESS-lisäosa automatisoi peräkkäiset regressioanalyysit, ja siihen sisältyvä epäparametrinen bootstrap-menetelmä arpoo satunnaisesti halutun määrän (esim. $1000 \mathrm{kpl}$ ) alkuperäisen vastaajajoukon kokoisia vaihtoehtoisia otoksia ja testaa epäsuoraa yhteyttä niistä jokaisessa (Hayes 2017). Bootstrap käsittelee siis alkuperäistä otosta representaationa populaatiosta, jolloin voidaan tutkia epäsuoran yhteyden vaihtelua erilaisissa otoksissa joutumatta kuitenkaan keräämään uutta aineistoa. Epäparametrinen bootstrap-menetelmä lievittää myös pieneen aineistoon liittyviä haasteita, sillä se ei tee jakaumaoletuksia ja luo tuhansittain uusia, vaihtoehtoisia otoksia (Caron 2019; Williams \& MacKinnon 2008). Tässä tutkimuksessa aineistosta muodostettiin 5000 vaihtoehtoista otosta, joissa jokaisessa testattiin epäsuorien yhteyksien toteutumista. Epäsuora yhteys on tilastollisesti merkitsevä, mikäli 95 prosentin luottamusväli ei sisällä nollaa. Tämä tarkoittaa sitä, että tarkasteltu epäsuora yhteys havaitaan vähintään 950 otoksessa tuhannesta.

Tällä analyysillä tutkittiin riippumattoman muuttujan (valtuuttava johtaminen) suoria ja epäsuoria eli psykologisten perustarpei- 
den peräkkäisen täyttymisen välittämiä yhteyksiä riippuvaan muuttujaan (työn imu). Tutkitut yhteydet löytyvät kuviosta 3. A-polut kuvaavat riippumattoman muuttujan yhteyksiä välittäviin tekijöihin, ja b-polut välittävien tekijöiden yhteyksiä riippuvaan muuttujaan. Polut $d_{1}$ ja $d_{2}$ viittaavat puolestaan välittävien tekijöiden keskinäisiin yhteyksiin (autonomiayhteenkuuluvuus ja autonomia-kompetenssi). Autonomian ja kahden muun tarpeen välisten peräkkäisten yhteyksien lisäksi mallissa on kompetenssin ja yhteenkuuluvuuden rinnakkaiset yhteydet, jotka eivät kuitenkaan vaikuta toisiinsa. Polku c' kuvaa riippumattoman muuttujan suoraa yhteyttä riippuvaan muuttujaan silloin, kun välittävät tekijät on kontrolloitu, ja kokonaisyhteys c taas riippumattoman muuttujan kokonaisvaltaista (suoran yhteyden ja epäsuorat yhteydet summaavaa) yhteyttä riippuvaan muuttujaan.

Hypoteesien keskiössä olevat epäsuorat peräkkäiset yhteydet ovat yhteyksien $a_{2}, d_{1}$ ja $b_{1}$ sekä $a_{2}, d_{2}$ ja $b_{3}$ tuloja. Polku $a_{2} d_{1} b_{1}$ on valtuuttavan johtamisen epäsuora yhteys työn imuun autonomian ja yhteenkuuluvuuden peräkkäisen täyttymisen kautta: autonomian täyttyminen on yhteydessä yhteenkuuluvuuden tarpeen täyttymiseen, mikä taas on yhteydessä koettuun työn imuun. Polku $\mathrm{a}_{2} \mathrm{~d}_{2} \mathrm{~b}_{3} \mathrm{ku}$ vaa samaan tapaan valtuuttavan johtamisen epäsuoraa yhteyttä työn imuun autonomian ja kompetenssin peräkkäisen täyttymisen kautta (valtuuttava johtaminen $->$ autonomia $->$ kompetenssi -> työn imu). Analyysissa vakioitiin iän, sukupuolen sekä ammatillisen koulutuksen taustamuuttujat.

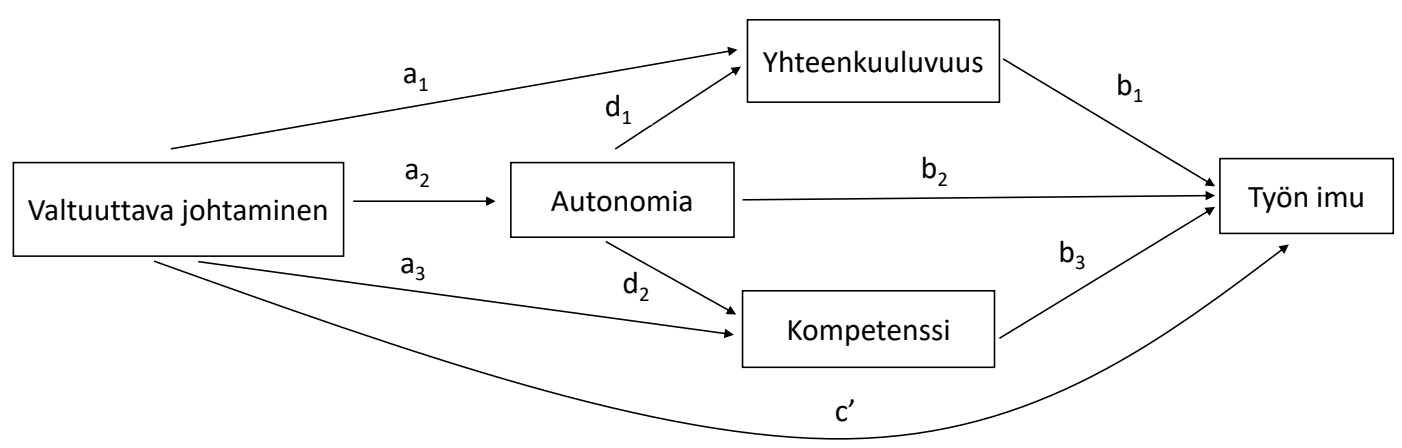

Kuvio 3. Tutkitut yhteydet

\section{Tulokset}

Muuttujien kuvailevat tunnusluvut ja keskinäiset korrelaatiot löytyvät taulukosta 2 . Kuvio 4 esittää valtuuttavan johtamisen ja työn imun väliset yhteydet autonomian, kompetenssin ja yhteenkuuluvuuden tarpeiden täyttymisen kautta. Mediaatioanalyysissa (5000 otoksen bootstrap-menetelmä, 95 \%:n luottamusväli) riippumaton muuttuja oli merkitsevästi yhteydessä vain yhteen välittävään tekijään, ja kaikki välittävät tekijät puolestaan riippuvaan muut- tujaan. Riippumattoman ja riippuvan muuttujan välinen kokonaisyhteys oli tilastollisesti merkitsevä, kun taas välittäviltä tekijöiltä kontrolloitu suora yhteys ei.

Hypoteesin 1 mukaisesti valtuuttavan johtamisen yhteys työn imuun välittyi autonomian tarpeen täyttymisen kautta $(\beta=.10, \mathrm{LV}=$ .03 -.18). Hypoteesien 2 ja 3 mukaisesti autonomian täyttyminen selitti kompetenssin ja yhteenkuuluvuuden täyttymistä, ja tämä psykologisten perustarpeiden peräkkäinen täyttyminen välitti valtuuttavan johtamisen ja 
työn imun välistä yhteyttä. Autonomian ja kompetenssin peräkkäinen täyttyminen välitti merkitsevästi valtuuttavan johtamisen yhteyttä työn imuun (a2d2b3):.171(.538).305=.028, $\mathrm{LV}=.002-.061$. Valtuuttava johtaminen oli siis positiivisessa yhteydessä työntekijöiden autonomian tarpeen täyttymiseen (a1), mikä taas oli positiivisessa yhteydessä kompetenssin täyttymiseen (d2), ja kompetenssin täyttyminen puolestaan työn imuun (b3). Autonomian ja kompetenssin peräkkäisen täyttymisen osuus valtuuttavan johtamisen ja työn imun välisestä kokonaisyhteydestä oli 10 prosenttia $\left(\mathrm{P}_{\mathrm{m}=} .10\right)$.

Myös autonomian ja yhteenkuuluvuuden peräkkäinen täyttyminen välitti merkitsevästi valtuuttavan johtamisen ja työn imun välistä yhteyttä (a2d1b1): .171(.56).349= .034,
$\mathrm{LV}=.002-.083$. Valtuuttava johtaminen oli positiivisessa yhteydessä autonomian tarpeen täyttymiseen (a1), mikä oli positiivisessa yhteydessä yhteenkuuluvuuden täyttymiseen (d1), ja yhteenkuuluvuuden täyttyminen taas työn imuun (b1). Valtuuttavan johtamisen ja työn imun välisestä kokonaisyhteydestä 12 prosenttia $\left(\mathrm{P}_{\mathrm{m}} .12\right)$ selittyi autonomian ja yhteenkuuluvuuden peräkkäisellä täyttymisellä.

Kaiken kaikkiaan mediaatioanalyysien tulokset tukevat asetettuja hypoteeseja. Suorasta yhteydestä poiketen havaitut epäsuorat peräkkäiset yhteydet ovat merkitseviä ja positiivisia: sekä autonomian ja kompetenssin että autonomian ja yhteenkuuluvuuden peräkkäinen täyttyminen välittää valtuuttavan johtamisen ja työn imun välistä yhteyttä.

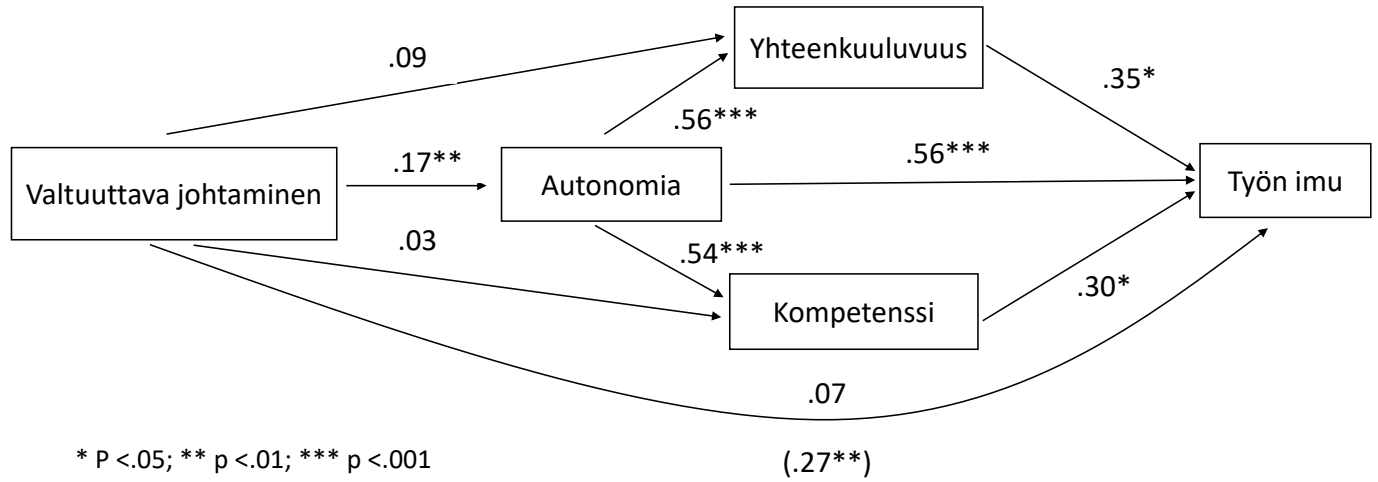

Kuvio 4. Mediaatioanalyysin tulokset: valtuuttavan johtamisen, autonomian, kompetenssin, yhteenkuuluvuuden ja työn imun väliset regressiokertoimet ja merkitsevyystasot

\section{Johtopäätökset}

Vahvasta teoreettisesta perustasta huolimatta autonomian erityisroolia ei ole huomioitu riittävästi aiemmissa tutkimuksissa. Tutkimuksemme vastasi omalta osaltaan tähän puutteeseen täydentäen ymmärrystä psykologisten perustarpeiden merkityksestä työelämässä. Tutkimustulokset olivat valittujen teoreettisten vii- tekehysten ja asetettujen hypoteesien mukaisia. Autonomian ja kompetenssin sekä autonomian ja yhteenkuuluvuuden peräkkäinen täyttyminen välittivät valtuuttavan johtamisen yhteyttä työntekijöiden kokemaan työn imuun.

Yksittäisistä psykologisista perustarpeista autonomia oli ainut, jonka kautta valtuuttavan johtamisen yhteys työn imuun välittyi. Peräkkäisistä epäsuorista yhteyksistä poike- 
ten valtuuttavan johtamisen suora yhteys työn imuun ei ollut merkitsevä. Toisin sanoen, mikäli tuloksia tarkastellaan itsemääräytymisteorian kuvaamien kausaalisuhteiden kautta, johtamisen täytyy myötävaikuttaa työntekijöiden psykologisten perustarpeiden täyttymiseen, ja näistä erityisesti autonomiaan, vaikuttaakseen heidän kokemaan työn imuun.

Autonomia selitti kompetenssin ja yhteenkuuluvuuden täyttymisen vaihtelua, jota valtuuttava johtaminen taas ei selittänyt. Tätä voisi selittää se, että riippumattomat ympäristömuuttujat (esim. esimieskäytännöt sekä työn voimavarat ja vaatimukset) ovat mahdollisesti herkemmin yhteydessä autonomian kuin kompetenssin tai yhteenkuuluvuuden tarpeen täyttymiseen. Toisaalta valtuuttava johtaminen (työntekijöiden vaikutusmahdollisuuksien, vastuun ja vapauden lisääminen) on itsessään jo käsitteellisestikin lähempänä autonomiaa kuin kompetenssia ja yhteenkuuluvuutta. Valtuuttavan johtamisen määritelmään sisältyy kuitenkin käsitys siitä, että esimies huolehtii työntekijöiden riittävästä osaamisesta ja tarjoaa esimerkiksi lisäkoulutusmahdollisuudet sekä tukea ja luottamusta tukien näin myös kompetenssin ja yhteenkuuluvuuden tarpeiden täyttymistä. Jatkotutkimuksissa voitaisiinkin selvittää, onko autonomia "herkempi" työympäristön vaikutuksille kuin kompetenssi ja yhteenkuuluvuus, ja voiko autonomia toimia linkkinä muiden työhön liittyvien tekijöiden ja työntekijöiden hyvinvoinnin välillä olemalla myös positiivisesti yhteydessä kompetenssin ja yhteenkuuluvuuden täyttymiseen.

Itsemääräytymisteoriaan ja saatuihin tuloksiin pohjautuen autonomian erityisroolin tutkiminen ja tukeminen ovat siis perusteltuja. Ensinnäkin autonomian täyttyminen edistää muiden psykologisten perustarpeiden, kompetenssin ja yhteenkuuluvuuden, toteutumista, mikä myötävaikuttaa tutkitusti myönteisiin lopputuloksiin sekä yksilö- että organisaatiotasolla (ks. Van den Broeck ym. 2016). Psykologisten perustarpeiden edistäminen on myös kustannustehokasta ja verraten vaiva- tonta, sillä se ei vaadi kalliita koulutuksia tai suuria investointeja, vaan niitä voidaan edistää hyvillä organisaatiokäytännöillä ja arkisessa vuorovaikutuksessa. Psykologiset perustarpeet eivät ole ajasta ja paikasta riippuvainen muoti-ilmiö. Ne ovat läsnä jokaisessa työntekijässä iästä, koulutuksesta tai alasta riippumatta ja tuovat toteutuessaan organisaatiolle ja yksilölle hyödyllisiä lopputuloksia, kuten kohentunutta hyvinvointia, motivaatiota ja työssä jaksamista niin lyhyellä kuin pitkällä aikavälillä. Tämä taas näkyy organisaatioiden menestyksessä ja kilpailukyvyssä.

Autonomialle on tarjontaa ja kysyntää työelämässä. Nykypäivän organisaatioissa vallitsevat yhä useammin matalat hierarkiat. Asiantuntijatyö ja itseohjautuvuus tarjoavat mahdollisuuden autonomiselle työnteolle. Lisäksi työltä halutaan entistä enemmän merkityksellisyyttä (Järvensivu \& Piirainen 2015), ja työ nähdään keinona toteuttaa itseään ja elää omien arvojen mukaista elämää. Tämä vaatii mahdollisuutta valita ja vaikuttaa omaan toimintaan, siis autonomiaa.

Valtuuttava johtaminen tukee esimieskäytännöistä eniten työntekijöiden autonomiaa antamalla sopivasti vastuuta ja riittävästi vapautta vaikuttaa oman työn tapoihin, aikoihin ja paikkoihin. Toisaalta valtuuttavassa johtamisessa ja työntekijöiden liiallisessa itseohjautuvuudessa on riskinä se, että työntekijä jää ilman riittävää tukea. Tähän tulee kiinnittää erityistä huomiota työjärjestelyissä ja -tavoissa sekä arkisessa vuorovaikutuksessa. Esimerkiksi selkeästi määritellyt tavoitteet, mutta joustavat menetelmät niiden saavuttamiseksi, edistävät yksilöiden autonomian tuntemuksia heidän voidessaan toimia parhaaksi näkemillään tavoilla sekä mahdollisesti hyödyntäen työaikajoustoja tai etätyömahdollisuuksia. Esimies tukee autonomiaa myös olemalla kiinnostunut työntekijöiden mielipiteistä.

Työntekijöiden kompetenssin tarpeen täyttymistä voidaan edistää rekrytoinnista lähtien. Organisaatioiden on tunnistettava ja viestittävä selkeästi tarvitsemansa osaaminen, johon työnhakija voi puolestaan vastata koulutuk- 
sellaan, kokemuksellaan ja henkilökohtaisilla ominaisuuksillaan eli kompetenssillaan. Henkilöstön kompetenssia tulee tukea koko työuran ajan alkaen hyvästä perehdytyksestä ja jatkuen lisäkoulutus-ja etenemismahdollisuuksien tarjoamiseen.

Esimiehen kuuluu myös huolehtia yleisestä työilmapiiristä, jolla on merkittävä vaikutus siihen, tuntevatko työntekijät olevansa arvostettuja ja hyväksyttyjä sellaisina kuin ovat. Esimies voi edistää hyvää ryhmähenkeä ja yhteenkuuluvuutta myös työpaikan arkisissa käytännöissä järjestämällä esimerkiksi säännöllisesti yhteisiä aamupalahetkiä, kahvitaukoja tai virkistysiltapäiviä. Työjärjestelyt, esimerkiksi työpari- ja tiimityöskentely, voivat myös hyvin toimiessaan edistää yhteenkuuluvuutta. Viihtyvyys ja yhteenkuuluvuus työyhteisössä edistävät yksilöiden hyvinvointia ja motivaatiota, ja näihin nojautuen voikin perustellusti kyseenalaistaa pitkään vallinneita, yleisiä suomalaisia työasenteita ja ankaraa työetiikkaa, joiden mukaan työssä ei tarvitse viihtyä ja työpaikalla tulisi välttää sosiaalista seurustelua.

Tämän tutkimuksen heikkoutena on pieni ja homogeeninen aineisto sekä poikkileikkausasetelma. Epäparametrinen bootstrapmenetelmä kuitenkin lievittää aineistoon liittyviä ongelmia, sillä se esimerkiksi ei tee jakaumaoletuksia ja luo tuhansittain vaihtoehtoisia otoksia (Caron 2019; Williams \&

\section{Kirjallisuus}

Ahonen, G. (2013) Työelämä ja sen muutos. Teoksessa T. Kauppinen, P. Mattila-Holappa, M. Perkiö-Mäkelä, A. Saalo, J. Toikkanen, S. Tuomivaara, S. Uuksulainen, M. Viluksela \& S. Virtanen (toim.) Työ ja terveys Suomessa 2012 - Seurantatietoa työoloista ja työhyvinvoinnista. Helsinki: Työterveyslaitos, 11-15.

Alasoini, T. (2015) Psykologinen sopimus organisaation ja työntekijöiden yhteisenä etuna. Teoksessa P. Pyöriä (toim.) Työhyvinvointi ja organisaation menestys. Helsinki: Gaudeamus, 99-118.

Bakker, A. B., Demerouti, E., \& Euwema, M.C. (2005)
MacKinnon 2008). Vaikka aineisto on pienempi kuin useimmissa vastaavissa tutkimuksissa, on mielekkäitä rinnakkaisia mediaatioyhteyksiä havaittu niinkin pienessä kuin 49 vastaajan otoksessa (ks. Ebersold ym. 2019). Poikkileikkaustutkimus tekee mahdottomaksi tutkia varsinaisia kausaalisuhteita, joten tutkimuksessa keskityttiin itsemääräytymisteorian kuvaamiin kausaalisiin yhteyksiin. Itsearviointi tutkimusmenetelmänä on myös ongelmallinen, sillä siitä ei pystytä päättelemään työyhteisön kokonaistilannetta tai esimiehen todellisia johtamiskäytäntöjä. Toisaalta kokemuksellisesta ilmiöistä, kuten psykologisten perustarpeiden täyttymisestä tai työn imusta, ei juuri muilla keinoin saa tietoa. Tutkimusaihe kaipaa lisätutkimusta suuremmilla ja monipuolisemmilla otoksilla sekä pitkittäistutkimusasetelmilla.

\section{Kirjoittajat}

Jenna Ryynänen, PsM, henkilöstökonsultti, psykologi, Psycon Oy, sähköposti: jenna.ryynanen@psycon.com Anniina Simonen, PsM, psykologi, Kruunupuisto $\mathrm{Oy}$, sähköposti: anniina.simonen@kruunupuisto.fi Petri Karkkola, PsT, yliopistonlehtori, Itä-Suomen yliopisto, sähköposti: petri.karkkola@uef.fi

Job resources buffer the impact of job demands on burnout. Journal of Occupational Health Psychology 10 (2), 170-180. https://doi.org/10.1037/1076-8998.10.2.170

Bakker, A. B., \& Demerouti, E. (2017) Job demandsresources theory: Taking stock and looking forward. Journal of Occupational Health Psychology 22 (3), 273-285. https://doi.org/10.1037/ocp0000056

Biggs, A., Brough, P. \& Barbour, J. P. (2014) Enhancing work-related attitudes and work engagement: A quasi-experimental study of the impact 
of an organizational intervention. International Journal of Stress Management 21 (1), 43-68. https://doi.org/10.1037/a0034508

Caron, P-O. (2019) A comparison of the type I error rates of three assessment methods for indirect effects. Journal of Statistical Computation and Simulation 89 (8), 1343-1356. https://doi.org/10.1 080/00949655.2019.1577858

Christian, M., Garza, A. \& Slaughter, J. (2011) Work engagement: a quantitative review and test of its relations with task and contextual performance. Personnel Psychology 64 (1), 89-136. https:// doi.org/10.1111/j.1744-6570.2010.01203.x

Deci, E. L., Ryan, R. M., Gagné, M., Leone, D.R., Usunov, J., \& Kornazheva, B.P. (2001) Need satisfaction, motivation, and well-being in the work organizations of a former Eastern Bloc country: A cross-cultural study of self-determination. Personality and Social Psychology Bulletin 27 (8) 930-942. https://doi.org/10.1177/0146167201278002

Deci, E., Olafsen, A. \& Ryan, R. (2017) Self-determination theory in work organizations: The state of a science. Annual Review of Organizational Psychology and Organizational Behavior 4 (1), 19-43. https://doi.org/10.1146/annurev-orgpsych-032516-113108

Deci, E. L., \& Ryan, R.M. (2017) Self-determination: basic psychological needs in motivation, development and wellness. New York: The Guildford Press.

Ebersold, S., Rahm, T. \& Heise, E. (2019) Autonomy support and well-being in teachers: differential mediations through basic psychological need satisfaction and frustration. Social Psychology of Education 22 (4), 921-942. https://doi.org/10.1007/s11218-019-09499-1

Elo, A., Dallner, M., Gamberale, F., Hottinen, V., Knardahl, S., Lindström, K., Skogstad, A. \& Örgede, E. (2001) QPS Nordic käsikirja 2001. Helsinki: Työterveyslaitos.

Gillet, N., Fouquereau, E., Forest, J., Brunault, P. \& Colombat, P. (2011) The impact of organizational factors on psychological needs and their Relations with well-being. Journal of Business and Psychology 27 (4), 437-450. https://doi.org/10.1007/s10869-011-9253-2

Gillet, N., Colombat, P., Michinov, E., Pronost, A-M. \& Fouquereau, E. (2013) Procedural justice, supervisor autonomy support, work satisfaction, organizational identification and job performance: The mediating role of need satisfaction and perceived organizational support. Journal of Advanced Nursing 69 (11), 2560- 2571.

https://doi.org/10.1111/jan.12144

Gillet, N., Fouquereau, E., Huyghebaert, T. \& Colombat, P. (2016) Effects of perceived organizational support and job characteristics and burnout: The mediating role of psychological need satisfaction. Psychologie Francaise 61 (2), 73-81. https://doi.org/10.1016/j.psfr.2014.05.004

Hakanen, J. (2009) Työn imun arviointimenetelmä. Työn imu -menetelmän (Utrecht Work Engagement Scale) käyttäminen, validointi ja viitetiedot suomessa. Helsinki: Työterveyslaitos.

Hakanen, J. (2011) Työn imu. Helsinki: Työterveyslaitos.

Hakanen, J. J. \& Roodt, G. (2010) Using the job demands-resources model to predict engagement: Analysing a conceptual model. Teoksessa A. B Bakker \& M. P. Leiter (toim.) Work engagement: A handbook of essential theory and research. Hove \& New York: Psychology Press, 82-105.

Halbesleben, J. R. B. (2010) A meta-analysis of work engagement: Relationships with burnout, demands, resources, and consequences. Teoksessa A. B. Bakker \& M. P. Leiter (toim.) Work engagement: A handbook of essential theory and research. Hove \& New York: Psychology Press, 102-117.

Hayes, A.F. (2017) Introduction to Mediation, Moderation, and Conditional Process Analysis: A Regression-Based Approach. New York: Guilford Publications.

Järvensivu, A. \& Piirainen, T. (2015) Hyvän työn ehdot työpaikan arjessa. Teoksessa P. Pyöriä (toim.) Työhyvinvointi ja organisaation menestys. Helsinki: Gaudeamus, 80-98.

Kansaneläkelaitos (2012) Kelan ASLAK-kurssien sisältö- ja hakuohjeita. [online]. <URL: http://www. kela.fi/documents/10180/12149/aslak_ohjeet. pdf>. Luettu 14.11.2017.

Kanter, R. M. (1977) Men and Women of the Corporation. New York: Basic Books.

Karkkola, P., Kuittinen, M. \& Van den Broeck, A. (2019) Psykologisten perustarpeiden työssä täyttymisen suomenkielinen kysely. Psykologia 54 (2), 91-105.

Kovjanic, S., Schuh, S. C., Jonas, K., Van Quaquebeke, N. \& Van Dick, R. (2012) How do transformational leaders foster positive employee outcomes? A self-determination-based analysis of employees' needs as mediation links. Journal of Organi- 
zational Behavior 33 (8), 1031-1052.

https://doi.org/10.1002/job.1771

Leiter, M. P. \& Bakker, A. B. (2010) Work engagement: Introduction. Teoksessa A. B. Bakker \& M. P. Leiter (toim.) Work engagement: A handbook of essential theory and research. Hove \& New York: Psychology Press, 1-9.

Lysova, E. I., Allan, B., Dik, B., Duffy, R. \& Steger, M. (2019) Fostering meaningful work in organizations: A multi-level review and integration. Journal of Vocational Behaviour 110 (B), 374-389. https://doi.org/10.1016/j.jvb.2018.07.004

Lämsä, A-M. \& Päivike, T. (2013) Organisaatiokäyttäytymisen perusteet. Helsinki: Edita

Martela, F. \& Jarenko, K. (2017) Itseohjautuvuus tulee, oletko valmis? Teoksessa F. Martela \& K. Jarenko (toim.) Itseohjautuvuus - Miten organisoitua tulevaisuudessa? Helsinki: Alma Talent, 9-32.

Martela, F. \& Pessi, A. (2018) Significant work is about self-realization and broader purpose: Defining the key dimensions of meaningful work. Frontiers in Psychology 9. https://doi.org/10.3389/fpsyg.2018.00363

Maynard, M. T, Gilson, L. L., \& Mathieu, J. E. (2012) Empowerment - Fad or fab? A multilevel review of the past two decades of research. Journal of Management 38 (4), 1231-1281.

https://doi.org/10.1177/0149206312438773

Pervin, L. A. (2003) Motivational units of personality. Teoksessa L. A. Pervin: The science of personality. Oxford: Oxford University Press, $104-145$

Salanova, M., Agut, S., \& Peiró, J. M. (2005) Linking organizational resources and work engagement to employee performance and customer loyalty: The mediation of service climate. Journal of Applied Psychology 90 (6), 1217-1227. https://doi.org/10.1037/0021-9010.90.6.1217

Schaufeli, W.B. \& Bakker, A. B. (2010) Defining and measuring work engagement: Bringing clarity to the concept. Teoksessa A. B. Bakker \& M. P. Leiter (toim.) Work engagement: A handbook of essential theory and research. Hove \& New York: Psychology Press, 10-24.

Schaufeli, W. B. \& Taris, T. W. (2014) A critical review of the job demands-resources model:
Implications for improving work and health. Teoksessa G. F. Bauer, \& O. Hämmig (toim.) Bridging occupational, organizational and public health: A transdisciplinary approach. Dordrecht: Springer, 43-68.

Spreitzer, G. M. (1995) Psychological empowerment in the workplace: Dimensions, measurement, and validation. Academy of Management Journal 38 (5), 1442-1465. https://doi.org/10.5465/256865

Työ- ja elinkeinoministeriö (2019) Työolobarometri 2018 - ennakkotiedot. Helsinki: Työ- ja elinkeinoministeriö.

Van den Broeck, A., Vansteenkiste, M., De Witte, H. \& Lens, W. (2008) Explaining relationships between job characteristics, burnout, and engagement: The role of basic psychological need satisfaction. Work and Stress 22 (3), 277-294. https://doi.org/10.1080/02678370802393672

Van den Broeck, A., Vansteenkiste, M., Witte, H., Soenens, B. \& Lens, W. (2010) Capturing autonomy, competence, and relatedness at work: Construction and initial validation of the work-related basic need satisfaction scale. Journal of Occupational and Organizational Psychology 83 (4), 981-1002.

https://doi.org/10.1348/096317909X481382

Van den Broeck, A., Ferris, D. L., Chang, C-H. \& Rosen, C.C. (2016) A review of self-determination theory's basic psychological needs at work. Journal of Management 42 (5), 1195-1229. https://doi.org/10.1177/0149206316632058

Williams, J. \& MacKinnon, D. P. (2008) Resampling and distribution of the product methods for testing indirect effects in complex models. Structural Equation Modeling: A Multidisciplinary Journal 15 (1), 23-51.

https://doi.org/10.1080/10705510701758166

Xanthopolou, D., Bakker, A., Demerouti, E. \& Schaufeli, W. (2009) Work engagement and financial returns: A diary study on the role of job and personal resources. Journal of Occupational and Organizational Psychology 82 (1), 183-200. https://doi.org/10.1348/096317908X285633 